\title{
KARAKTERISTIK YAYASAN SEBAGAI BADAN HUKUM DI INDONESIA
}

\author{
Oleh :
}

Ari Purwadi

\begin{abstract}
Foundation is a corporation that has particular aim in social, religiousness and humanism sector. Its corporate status is obtained after Ministry of Justice and Human Rights approved its Founding Document. The achievement of its aim and business activity is set based on the Statutes mentioned in the Founding Document which referring to the Foundation Regulation. While it has no members, foundation has components such as Advisors and Foundation Board in which, based on the transparency principles and public accountability, a control mechanism should be held, i.e.: 1 . Internal control, by the foundations component named Controller; 2 . Annual reports; 3 . Audit by Public Accountant; 4. Enquete Right by Attorney General or other concerned parties; and 5. Attorney General authority. As a component in the organization, the foundation board responsible for losses caused by ultra vires action and has a possibility of collective responsibility among the member of the board, or along with the advisor in case of a mistake or a carelessness that leads into a bankruptcy.
\end{abstract}

\section{PENDAHULUAN}

Undang-Undang Nomor 16 Tahun 2001

Tentang Yayasan (untuk selanjutnya ditulis Undang-Undang Yayasan) disahkan pada tanggal 6 Agustus 2001 dan mulai diberlakukan secara efektif pada tanggal 6 Agustus 2002. Beberapa pertimbangan ditetapkannya Undang-Undang Yayasan ini. Antara lain : belum adanya peraturan perundang-undangan mengenai yayasan, yayasan telah berkembang dengan pesat di berbagai kegiatan, maksud dan tujuan, serta untuk menjamin kepastian dan ketertiban hukum, agar yayasan berfungsi sesuai dengan maksud dan tujuannya.

Selama ini yayasan di Indonesia hanya berdasarkan atas kebiasaan dan yurisprudensi. Pada saat itu yayasan sebagai Badan Hukum kiranya tak seorangpun yang meragukannya meskipun belum ada undang-undang yang mengaturnya. Dalam lalu-lintas hukum sehari-hari yayasan sudah diperlakukan sebagai suatu legal entity, artinya diperlukan sebagai suatu kesatuan yang menyandang hak-hak dan kewajiban-kewajiban sendiri. Sebenarnya sudah sejak akhir abad ke-19, yurisprudensi di negeri Belanda berpendirian bahwa yayasan adalah suatu Badan Hukum. Pada tahun 1882 Badan Peradilan tertinggi di negeri Belanda, Hoge Raad, memberikan suatu putusan, bahwa yayasan sebagai Badan Hukum adalah sah menurut hukum dan karenanya dapat didirikan. Pendirian Hoge Raad tersebut diikuti oleh Hooggerechtshof, peradilan tertinggi di jaman pemerintahan Hindia Belanda dalam putusannya pada tahun 1884 .'

' Setiawan, "Tiga Aspek Hukum Yayasan", Varia Peradilan, Th. V No. 55 April 1990, h. 113. 
Di samping itu, diikuti oleh Mahkamah Agung Republik Indonesia tanggal 27 Juni 1973 Nomor 124/SIP/1973.

Selain yurisprudensi, para pakar hukum mengemukakan pendapatnya mengenai status badan hukum yayasan dengan memberikan batasan-batasan yang pada umumnya menggambarkan bahwa yayasan adalah suatu badan hukum. Maksudnya yayasan merupakan suatu kesatuan yang berwenang untuk melakukan perbuatan hukum. tidak mempunyai anggota, adanya harta kekayaan terpisah, adanya tujuan yang bersifat sosial kemasyarakatan, adanya organisasi yang mengurus kekayaan yayasan untuk mencapai tujuan dan kegiatan yayasan serta adanya Akta Pendirian Yayasan sebagai persyaratan formal. ${ }^{2}$ Sementara itu, Chidir Ali mengatakan bahwa karena tidak terdapat perundangundangan yang mengatur yayasan secara khusus, maka hukum yang berlaku baginya adalah kebiasaan dan yurisprudensi yang mensyaratkan bagi adanya yayasan sebagai badan hukum, yaitu : a. harus terdapat pemisahan kekayaan, b. penunjukkan suatu tujuan tertentu, dan c. penunjukkan suatu organisasi. ${ }^{3}$

Pendirian yayasan dianggap sah menurut kebiasaan apabila memenuhi syarat:

a. pendiri yayasan meminta jasa seorang Notaris untuk membuat Akta Pendirian atau Anggaran Dasar Yayasan;

b. selanjutnya pengurus yayasan mengurus domisili yayasan pada kepala

${ }^{2}$ R.F. Saragih, "Yayasan dan Permasalahan di Indonesia Era Hukum, No. 3, Th. VI Januari 2000, h. 247 .

${ }^{3}$ Chidir Ali, Badan Hukum, Alumni Bandung, 1976, h. 66. pemerintahan di tempat kedudukan yayasan, mengurus SIUP pada instansi yang berwenang sesuai dengan kegiatan yayasan.

c. Akta pendirian yayasan didaftarkan pada Penitera Pengadilan Negeri yang wilayah hukumnya mencangkup tempat kedudukan yayasan; dan

d. Akta pendirian atau anggaran dasar yayasan tersebut diumumkan dalam

Tambahan Berita Negara Republik Indonesia."

Yayasan harus mempunyai tujuan tertentu dan jelas. Tujuan tersebut harus ideal dan tidak boleh bertentangan dengan kesusilaan, ketertiban umum, hukum dan kepentingan umum. Yayasan tidak boleh mempunyai tujuan yang diarahkan kepada pencapaian keuntungan dan kepentingan kebendaan bagi pendirinya, karena yayasan bukan badan usaha perdagangan yang tidak hanya berharap mendapat keuntungan tetapi juga mengandung kemungkinan resiko untuk menderita kerugian, yang dapat mengakibatkan tujuan sosial yayasan tidak tercapai.

Asal mula bentuk yayasan klasik dikenal di negeri Belanda hanya suatu lembaga yang dipergunakan untuk tujuan-tujuan idiil, khususnya tujuan sosial. Namun, pada pertengahan abad ke- 20 bentuk hukum ini mulai banyak dipergunakan pula untuk lapangan diluar tujuan sosial, yang kemudian memasuki pula lapangan perusahaan yang pada hakekatnya mempunyai tujuan komersiil, bahkan untuk kepentingan kegiatan badanbadan publik mengambil bentuk yayasan,

\footnotetext{
${ }^{4}$ R.F. saragih, Loc.cit.

sibid.
} 
seperti "Stichting Drinkwater-leiding Weet Utrecht yang didirikan oleh propinsi Utrecht pada tahun $1925 .^{6}$ Fenomena yang timbul banyak penyalahgunaan dan pelarian kepada bentuk yayasan yang mestinya harus mempergunakan bentuk Perseroan Terbatas, sehingga timbul yayasan yang ada merupakan suatu Perseroan Terbatas terselubung.? Berdasarkan pertimbangan untuk kepentingan umum, agar tidak terjadi ketidakpastian hukum mengenai yayasan, maka negeri Belanda telah mengatur yayasan dalam "Wet op Stichting 31 Mei 1956, S. 327", yang kemudian berkali-kali telah mengalami perubahan dengan Wet 9 Desember $1959 \mathrm{~S}$. 450 dan Wet 13 Juni 1963 S. 284, serta Wet 10 Juli 1963 S. $297 .^{8}$ Pada tahun 1976 UndangUndang Yayasan di negeri Belanda diinkorporasikan ke dalam Buku II BW yang mengatur tentang Badan Hukum (Buku II Titel ke-5 pasal 285 s/d 305 BW Baru). ${ }^{9}$

Fenomena ini barangkali mirip dengan yang terjadi di negara kita, sehingga lahirlah Undang-Undang Yayasan yang disahkan pada tanggal 6 Agustus 2001 sebagaimana yang tercantum pada Penjelasan Umum UndangUndang Yayasan tersebut. Dalam Penjelasan Umum tersebut dijelaskan : "Fakta menunjukkan kecenderungan masyarakat mendirikan yayasan dengan maksud untuk berlindung dibalik status Badan Hukum Yayasan, yang tidak hanya digunakan sebagai wadah mengembangkan kegiatan sosial, keagamaan, kemanusiaan, melainkan

\footnotetext{
${ }^{6}$ Rdhi Prasetya dan A. Oemar Wongsodiwiryo, Dasar-Dasar Hukum Persekutuan, tanpa penerbit, 1976 , h. 47.

7 lbid, h. 47.

${ }^{8}$ Ibid., h. 50

${ }^{9}$ Setiawan, Loc.cit.
}

Juga adakalanya bertujuan untuk memperkaya diri para Pendiri, Pengurus dan Pengawas". Selanjutnya dijelaskan bahwa: "Undang-Undang ini dimaksudkan untuk memberikan pemahaman yang benar kepada masyarakat mengenai yayasan, menjamin kepastian dan ketertiban hukum serta mengembalikan fungsi yayasan sebagai pranata hukum dalam rangka mencapai tujuan tertentu di bidang sosial, keagamaan, dan kemanusiaan".

Tulisan ini akan mencoba menelaah aspek-aspek hukum apa yang perlu diperhatikan mengenai yayasan sebagaimana yang diatur dalam Undang-Undang Yayasan. Ada 3 aspek yang perlu ditelaah, yaitu : 1 . Bagaimanakah karakteristik yayasan sebagai badan hukum ? 2. Bagaimanakah mekanisme pengawasan yayasan ? dan 3 . Bagaimana kewenangan bertindak pengurus dan pertanggungjawaban yayasan terhadap Pihak ke-3 ?.

\section{YAYASAN SEBAGAI BADAN HUKUM}

Dengan adanya Undang-Undang Yayasan ini, maka untuk pendirian yayasan Ini menggunakan sistem konsesi (concessie system), yaitu suatu sistem yang menyatakan syarat pendirian suatu organisasi hanya memperoleh status badan hukum setelah diperoleh pengesahan dari penguasa. Sistem ini akan lebih mudah untuk melakukan pengawasan. ${ }^{10} \mathrm{Hal}$ ini diatur dalam pasal 11 Undang-Undang Yayasan yang menyatakan bahwa yayasan memperoleh status badan hukum setelah akta pendirian yayasan memperoleh pengesahan dari Menteri Kehakiman dan Hak Asasi Manusia. Dalam rangka memberikan pelayanan dan kemudahan bagi masyarakat, permohonan pendirian yayasan dapat diajukan kepada Kepala Kantor

\footnotetext{
${ }^{10}$ Ibid., h. 115.
} 
Wilayah Departemen Kehakiman dan Hak Asasi Manusia yang wilayah kerjanya meliputi tempat kedudukan yayasan. Di samping itu, yayasan yang telah memperoleh pengesahan harus diumumkan dalam Tambahan Berita Negara Republik Indonesia.

Pasal 1 angka 1 Undang-Undang Yayasan memberikan definisi tentang yayasan adalah badan hukum yang terdiri dari atas kekayaan yang dipisahkan dan diperuntukkan untuk mencapai tujuan tertentu di bidang sosial, keagamaan, dan kemanusiaan, yang tidak mempunyai anggota". Yayasan sebagai badan hukum didirikan oleh satu orang atau lebih dengan akta notaris (pasal 9 ayat (2) Undang-Undang Yayasan) dan memperoleh status sebagai badan hukum setelah akta pendiriannya itu disahkan oleh Menteri Kehakiman dan Hak Asasi Manusia. Selain itu, Undang-Undang Yayasan mengatur kemungkinan yayasan didirikan berdasarkan surat wasiat (pasal 9 ayat (3) Undang-Undang Yayasan). Surat wasiat ini berarti surat wasiat terbuka yang dibuat oleh notaris Indonesia dan bukan surat wasiat holograf atau surat wasiat rahasia yang dibuat di bawah tangan dan dideponir di notaris. Pendirian yayasan ini berbeda dengan pendirian Perseroan Terbatas. Pendirian yayasan adalah perbuatan hukum sepihak meskipun didirikan oleh lebih dari satu orang, sedangkan pendirian Perseroan Terbatas merupakan perjanjian antara para pendiri."

Akta pendirian memuat 1. Anggaran Dasar Yayasan dan 2. Keterangan lain yang dianggap perlu.

\footnotetext{
"Ratnawati W. Prasodjo, Mengembalikan Fungsi Yayasan sebagai Pranata Hukum dalam Rangka Mencapai Tujuan Tertentu di Bidang Sosial, Keagamaan dan Kemanusiaan, Makalah Seminar Undang-Undang No. 16 Tahun 2001, h.6.
}

Anggaran Dasar Yayasan memuat antara lain :

\section{a. Nama dan Tempat Kedudukan}

Mengenai hal ini Undang-Undang Yayasan mengatur:

$>$ nama yayasan tidak boleh memakai nama yang telah dipakai secara sah oleh yayasan lain atau bertentangan dengan ketertiban umum dan/atau kesusilaan.

$>$ Nama yayasan harus didahului dengan kata "Yayasan", demikian juga kata "Yayasan" mendahului kata wakaf apabila kekayaan yayasan berasal dari wakaf (pasal 15 Undang-Undang Yayasan)

$>$ Yayasan mempunyai tempat kedudukan dalam wilayah negara Republik Indonesia dengan menyebutkan nama kecamatan, kabupaten, kota dan propinsi apabila kedudukan yayasan disebutkan nama desa (pasal $4 \quad$ Undang-Undang Yayasan),

b. Maksud dan tujuan serta kegiatan untuk mencapai maksud dan tujuan tersebut

Mengenai hal ini Undang-Undang Yayasan mengatur:

$>$ yayasan dapat melakukan kegiatan usaha untuk menunjang pencapaian maksud dan tujuannya dengan cara mendirikan badan usaha dan / atau ikut serta dalam suatu badan usaha.

$>$ Yayasan tidak boleh membagikan hasil kegiatan usaha kepada Pembina, Pengurus, dan Pengawas (Organ yayasan) sesuai dengan maksud dan tujuan yayasan yang bersifat sosial, keagamaan dan kemanusiaan, sehingga seseorang yang menjadi anggota Pembina, Pengurus, Pengawas 
Yayasan harus bekerja secara sukarela tanpa menerima gaji, upah, atau honor tetap (pasal 3 Undang-Undang Yayasan).

$>$ Yayasan dapat mendirikan badan usaha yang kegiatannya sesuai dengan maksud dan tujuan yayasan serta tidak bertentangan dengan ketertiban dan / atau peraturan perundang-undangan yang berlaku dan dapat pula melakukan penyertaan dalam berbagai bentuk usaha yang bersifat prospektif dengan ketentuan seluruh penyertaan tersebut paling banyak $25 \%$ dari seluruh nilai kekayaan yayasan.

$>$ Anggota organ yayasan dilarang merangkap sebagai Direksi / Komisaris Badan Usaha yang didirikan tersebut (pasal 7 dan 8 Undang-Undang Yayasan).

\section{c. Jangka waktu pendirian}

Mengenai hal ini Undang-Undang Yayasan mengatur:

$>$ Yayasan dapat didirikan untuk jangka waktu tertentu atau tidak tertentu.

$>$ Yayasan yang didirikan untuk jangka waktu tertentu, pengurus dapat mengajukan perpanjangan jangka waktu pendirian kepada Menteri Kehakiman dan Hak Asasi Manusia paling lambat 1 (satu) tahun sebelum berakhirnya jangka waktu pendirian yayasan (pasal 16 Undang-Undang Yayasan).

\section{d. Jumlah kekayaan awal yang dipisahkan dari kekayaan pribadi pendiri dalam bentuk uang atau benda.}

\section{e. Cara memperoleh dan penggu-naan kekayaan}

Mengenai hal ini Undang-Undang Yayasan mengatur:

$>$ Kekayaan yayasan berasal dari sejumlah kekayaan yang dipisahkan dalam bentuk uang atau barang. Selain itu, kekayaan yayasan dapat diperbleh dari : a. Sumbangan atau bantuan yang tidak mengikat; b. wakaf; c. hibah; d. hibah wasiat; dan e. perolehan lain, seperti deviden, bunga tabungan bank, sewa gedung, perolehan dari hasil usaha yayasan (pasal 26 Undang-Undang Yayasan).

$>$ Kekayaan yayasan baik berupa uang, barang, maupun kekayaan lain yang diperoleh yayasan dilarang dialihkan atau dibagikan secara langsung atau tidak langsung kepada organ yayasan karyawan atau pihak lain yang mempunyai kepentingan terhadap yayasan (pasal 5 Undang-Undang Yayasan).

$>$ Yayasan wajib membayar segala biaya atau ongkos yang dikeluarkan oleh organ yayasan dalam rangka menjalankan tugas yayasan (pasal 6 Undang-Undang Yayasan).

f. Tata cara pengangkatan, pemberhentian, dan penggantian anggota Pembina, Pengurus, dan Pengawas.

Mengenai hal ini, Undang-Undang Yayasan mengatur:

$>$ Yayasan mempunyai organ yang terdiri dari Pembina, Pengurus, dan Pengawas (pasal 2 Undang-Undang Yayasan).

$>$ Pembina adalah organ yayasan. yang mempunyai kewenangan yang tidak 
diserahkan kepada pengurus atau pengawas oleh Undang-Undang Yayasan atau Anggaran Dasar.

$>$ Anggaran Pembina dapat diangkat dari pendiri yayasan dan / atau mereka yang berdasarkan rapat anggota pembina dinilai mempunyai dedikasi tinggi untuk mencapai maksud dan tujuan yayasan (pasal 28 UndangUndang Yayasan);

$>$ Pengurus adalah organ yayasan yang melaksanakan kepengurusan yayasan (pasal 31 ayat (1) Undang-Undang Yayasan) dan diangkat oleh pembina berdasarkan keputusan rapat pembina untuk jangka waktu selama 5 (lima) tahun dan dapat diangkat kembali untuk 1 (satu) kali masa jabatan (pasal 32 ayat (1) Undang-Undang Yayasan);

$>$ Pengawas adalah organ yayasan yang bertugas melaksanakan pengawasan serta memberi nasehat kepada pengurus dalam menjalankan kegiatan yayasan (pasal 40 ayat (1) Undang-Undang Yayasan) dan diangkat oleh pembina berdasarkan keputusan rapat pembina untuk jangka waktu selama 5 (lima) tahun dan dapat diangkat kembali untuk 1 (satu) kali masa jabatan.

g. Hak dan kewajiban anggota Pembina, Pengurus, dan Pengawas.

Mengenai hal ini Undang-Undang Yayasan mengatur:

$>$ Kewenangan pembina meliputi : a. keputusan mengenai perubahan anggaran dasar; $b$, pengangkatan dan pemberhentian anggota pengurus dan anggota pengawas; c. penetapan kebijakan umum yayasan berdasarkan anggaran dasar yayasan; d. pengesahan program kerja dan penetapan keputusan mengenai penggabungan atau pembubaran yayasan (pasal 28 ayat (2) UndangUndang Yayasan).

$>$ Pengurus yayasan bertanggung-jawab penuh atas kepengurusan yayasan untuk kepentingan dan tujuan yayasan serta berhak mewakili yayasan baik di dalam maupun di luar pengadilan. Setiap pengurus menjalankan tugas dengan itikad baik dan penuh tanggungjawab untuk kepentingan dan tujuan yayasan. Untuk menjalankan tugas, pengurus dapat mengangkat. pengurus harian yayasan (pasal 35 UndangUndang Yayasan).

\section{h. Tata cara penyelenggaraan rapat organ} yayasan

Mengenai hal ini Undang-Undang Yayasan mengatur:

$>$ Pembina mengadakan rapat tahunan untuk melakukan evaluasi tentang kekayaan, hak, dan kewajiban yayasan tahun yang lampau (pasal 30 UndangUndang Yayasan).

$>$ Rapat gabungan antara pengurus dan pengawas manakala terjadi kekosongan pembina untuk mengangkat pembina (pasal 28 ayat (4) Undang-Undang Yayasan).

$>$ Rapat pembina dapat memberhentikan pengurus sebelum masa kepengurusannya berakhir manakala pengurus selama menjalankan tugas dinilai melakukan tindakan yang merugikan yayasan (pasal 32 ayat (3) Undang-Undang Yayasan). 
I. Ketentuan mengenai perubahan Anggaran Dasar

Mengenai hal ini Undang-Undang Yayasan mengatur:

$>$ Anggaran Dasar dapat diubah, kecuali mengenai maksud dan tujuan yayasan (pasal 17 Undang-Undang Yayasan).

$>$ Perubahan Anggaran Dasar hanya dapat dilaksanakan berdasarkan keputusan rapat pembina dan dilakukan dengan akta notaris (pasal 18 UndangUndang Yayasan).

$>$ Perubahan Anggaran Dasar harus mendapat persetujuan Menteri Kehakiman dan Hak Asasi Manusia apabila perubahan itu mengenai nama dan kegiatan yayasan, sedangkan mengenai perubahan yang lain cukup diberitahukan kepada Menteri Kehakiman dan Hak Asasi Manusia (pasal 21 Undang-Undang Yayasan).

$>$ Perubahan Anggaran Dasar tidak dapat dilakukan pada saat yayasan dinyatakan pailit, kecuali atas persetujuan kurator (pasar 23 UndangUndang Yayasan).

j. Penggabungan dan pembubaran yayasan

Mengenai hal ini Undang-Undang Yayasan mengatur:

$>$ Penggabungan yayasan dapat dilakukan dengan memperhatikan : a, ketidakmampuan yayasan melaksanakan kegiatan usaha tanpa dukungan yayasan lain; b. yayasan yang menerima penggabungan dari yang bergabung kegiatannya sejenis; atau $\mathrm{c}$. yayasan yang menggabungkan diri tidak pernah melakukan perbuatan yang bertentangan dengan anggaran dasarnya, ketertiban umum, dan kesusilaan (pasal 57 Undang-Undang Yayasan).

$>$ Rancangan akta penggabungan yayasan dan akta perubahan Anggaran Dasar Yayasan yang menerima penggabungan wajib disampaikan kepada Menteri Kehakiman dan Hak Asasi Manusia untuk memperoleh persetujuan (pasal 60 Undang-Undang Yayasan).

$>$ Yayasan bubar karena :

a. jangka . waktu yang ditetapkan dalam Anggaran Dasar berakhir; .

b. tujuan yayasan yang ditetapkan dalam Anggaran Dasar telah tercapai atau tidak tercapai;

c. putusan pengadilan yang telah memperoleh kekuatan hukum tetap berdasarkan alasan :

1. Yayasan melanggar ketertiban umum dan kesusilaan;

2. Tidak mampu membayar utangnya setelah dinyatakan pailit; atau

3. Harta kekayaan yayasan tidak cukup untuk melunasi utangnya setelah pernyataan pailit dicabut (pasal 62 UndangUndang Yayasan).

$>$ Pembubaran yayasan akan ditunjuk likuidator untuk membereskan kekayaan yayasan bisa dilakukan oleh pembina, bisa juga dilakukan oleh pengadilan sesuai dengan alasan pembubaran (pasal 63 dan pasal 64 Undang-Undang Yayasan). 


\section{k. Penggunaan kekayaan sisa likuidasi atau penyaluran kekayaan yayasan setelah pembubaran.}

Mengenai hal ini Undang-Undang Yayasan mengatur:

$>$ Kekayaan sisa hasil likuidasi diserahkan kepada yayasan lain yang mempunyai maksud dan tujuan yang sama dengan yayasan yang bubar.

$>$ Apabila tidak diserahkan kepada yayasan lain tersebut, maka sisa kekayaan tersebut diserahkan kepada negara dan penggunaannya dilakukan sesuai dengan maksud dan tujuan yayasan tersebut (pasal 68 Undang-Undang Yayasan).

Mengenai keterangan lain yang dianggap perlu di antaranya memuat sekurangkurangnya nama, alamat, pekerjaan, tempat dan tanggal lahir, serta kewarganegaraan Pendiri, Pembina, Pengurus dan Pengawas. Langkah berikutnya, akta pendirian yayasan yang telah disahkan sebagai badan hukum atau terjadi suatu perubahan Anggaran Dasar Yayasan yang telah disetujui wajib diumumkan dalam Tambahan Berita Negara Republik Indonesia dengan mengajukan permohonan kepada Kantor Percetakan Negara Republik Indonesia (pasal 24 Undang-Undang Yayasan). Apabila tidak dilakukan / belum dilakukan pengumuman ini, maka Pengurus Yayasan bertanggungjawab secara tanggung renteng atas seluruh kerugian yayasan (pasal 25 Undang-Undang Yayasan).

Undang-Undang Yayasan ini juga mengatur ketentuan peradilan yang diatur dalam pasal 71. Bagi yayasan yang telah :

didaftarkan di Pengadilan Negeri dan diumumkan dalam Tambahan Berita

Negara; atau
- didaftarkan di Pengadilan Negeri dan mempunyai izin melakukan kegiatan dari instansi terkait, pada saat UndangUndang Yayasan berlaku tanggal 6 Agustus 2002, tetap diakui sebagai badan hukum dengan ketentuan paling lambat pada tanggal 6 Agustus 2007 wajib menyesuaikan anggaran dasarnya dengan ketentuan Undang-Undang Yayasan ini. Bagi yayasan yang telah menyesuaikan anggarannya paling lambat 1 (satu) tahun setelah pelaksanaan penyesuaian wajib memberitahukan kepada Menteri Kehakiman dan Hak Asasi Manusia. Sedangkan yayasan yang setelah lewatnya jangka waktu yang telah ditentukan tidak menyesuaikan dapat dibubarkan berdasarkan putusan pengadilan atas permohonan Kejaksaan atau pihak yang berkepentingan (pihak-pihak yang mempunyai kepentingan langsung dengan yayasan),

\section{PENGAWASAN YAYASAN}

Yayasan adalah suatu badan hukum yang tidak memiliki anggota, namun adanya organisasi merupakan syarat adanya suatu yayasan yang dinamakan organ yayasan. Oleh karena yayasan tidak mempunyai anggota, maka tidak dikenal adanya rapat anggota. Dengan demikian, masalah yang perlu diperhatikan adalah masalah pengawasan. Bentuk-bentuk pengawasan yayasan pada dasarnya dilakukan :

a. Pengawasan intern

Undang-Undang Yayasan memberikan kewenangan pengawasan yayasan melalui organ yayasan yaitu pengawas (pasal 40 Undang-Undang Yayasan). Dalam menjalankan wewenangnya, pengawas 
dapat memberhentikan sementara anggota pengurus dengan menyebutkan alasannya. Pemberhen-tian sementara tersebut wajib dilaporkan secara tertulis kepada pembina. Selanjutnya pembina berkewajiban untuk memberikan kesempatan kepada pengurus yang bersangkutan untuk diberi kesempatan membela diri. Setelah pembelaan diri pembina wajib untuk; a. mencabut keputusan pemberhentian sementara atau b. memberhentikan anggota pengurus yang bersangkutan (pasal 43 Undang-Undang Yayasan), Pada dasarnya pengawas tidak mempunyai fungsi eksekutif, walaupun anggaran dasar yayasan dapat mengatur bahwa untuk perbuatan hukum tertentu pengurus memerlukan persetujuan pengawas. Hal ini berarti bahwa pemberian persetujuan tersebut bukan merupakan perbuatan kepengurusan atau pemberian kuasa. Hanya dalam hal-hal tertentu yaitu dalam hal terjadinya benturan kepentingan antara yayasan dengan seluruh anggota pengurus, maka pengawas berwenang mewakili yayasan apabila hal tersebut diatur dalam anggaran dasar. ${ }^{12}$

b. Perhitungan Tahunan dan Laporan Tahunan

Adanya suatu perhitungan tahunan serta laporan tahunan mengenai keuangan merupakan suatu perlindungan hukum bagi pihak ke-3, serta jaminan untuk mencegah terjadinya manipulasi Undang-Undang Yayasan menentukan kewajiban pengurus dalam pasal 48 dan pasal 49 , yaltu : 1 . Kewajiban membuat dan menyimpan catatan atau tulisan yang berisi keterangan

${ }^{12}$ Ibid., h. 16. mengenai hak dan kewajiban serta hal lain yang berkaitan dengan kegiatan usaha yayasan; 2. Kewajiban membuat dan menyimpan dokumen keuangan yayasan berupa bukti pembukuan dan data pendukung administrasi keuangan; 3 . Kewajiban menyusun laporan tahunan secara tertulis paling lambat 5 (lima) bulan terhitung sejak tanggal tahun buku yayasan ditutup dengan memuat : a. laporan keadaan dan kegiatan yayasan selama tahun buku tahun yang lalu serta hasil yang telah dicapai, dan b. laporan keuangan yang terdiri atas laporan posisi keuangan pada akhir periode, laporan aktivitas, laporan arus kas dan catatan laporan keuangan; dan 4. Kewajiban mencantumkan hak dan kewajiban yayasan yang timbul dari transaksi yang diadakan oleh yayasan dengan pihak lain dalam laporan tahunan. Dalam pasal 52 UndangUndang Yayasan diatur bahwa ikhtisar laporan tahunan yayasan diumumkan pada papan pengumuman di kantor yayasan dan apabila yayasan tersebut : a. memperoleh bantuan negara, bantuan luar negeri atau pihak lain sebesar Rp 500.000.000,00 (lima ratus juta rupiah) atau lebih; atau b. mempunyai kekayaan di luar harta wakaf sebesar Rp 20.000.000.000,00 (dua puluh miliar rupiah) atau lebih. Wajib Ikhtisar laporan tahunannya diumumkan dalam surat kabar harian berbahasa Indonesia.

c. Audit oleh akuntan publik

Berdasarkan prinsip keterbukaan dan akuntabilitas publik, maka yayasan wajib diaudit oleh Akuntan Publik manakala yayasan tersebut : 1 . Memperoleh bantuan negara, bantuan luar negeri atau pihak lain sebesar Rp 500.000.000,00 (lima ratus juta 
rupiah) atau lebih b. memiliki kekayaan diluar harta wakaf sebesar $\mathrm{Rp}$ $20.000 .000 .000,00$ (dua puluh miliar rupiah). Hasil audit disampaikan kepada pembina yayasan yang bersangkutan dan tembusannya kepada Menteri Kehakiman dan Hak Asasi Manusia dan instansi terkait. (pasal 52 Undang-Undang Yayasan).

\section{d. Hak Enquete}

Hak enquete ini memberikan kemungkinan untuk diadakan suatu pemeriksaan yang tidak memihak terhadap kebijakan serta jalannya pengurusan apabila memang terdapat cukup alasan untuk itu. Alasan untuk mengadakan pemeriksaan apabila terdapat dugaan bahwa organ yayasan : a. Melakukan perbuatan melawan hukum atau bertentangan dengan Anggaran Dasar; b. Ialai dalam melaksanakan tugasnya; c. melakukan perbuatan yang merugikan yayasan atau pihak ke-3; atau d. melakukan perbuatan yang merugikan negara, Pemeriksaan hanya dapat dilakukan / berdasarkan penetapan pengadilan atas permohonan tertulis pihak ketiga yang berkepentingan disertai alasan. untuk dugaan huruf $\mathrm{a}, \mathrm{b}$, dan $\mathrm{c}$, atau dapat dilakukan berdasarkan penetapan pengadilan atas permintaan Kejaksaan dalam hal mewakili kepentingan umum untuk dugaan huruf $d$ (pasal 53 UndangUndang Yayasan). Pengadilan dapat menolak atau mengabulkan permohonan pemeriksaan. Dalam hal Pengadilan mengabulkan permohonan pemeriksaan terhadap yayasan, Pengadilan mengeluarkan penetapan bagi pemeriksaan dan mengangkat paling banyak 3 (tiga) orang ahli sebagai pemeriksa untuk melakukan pemeriksaan (pasal 54 Undang-Undang Yayasan). Pemeriksaan dilarang mengumumkan atau memberitahukan hasil pemeriksaannya kepada pihak lain dan wajib menyampaikan laporan hasil pemeriksaan kepada Ketua Pengadilan di tempat kedudukan yayasan. Ketua Pengadilan memberikan salinan laporan hasil pemeriksaan kepada pemohon atau Kejaksaan dan yayasan yang bersangkutan (pasal 56 Undang-Undang Yayasan).

e. Kewenangan Kejaksaan

Kewenangan Kejaksaan dalam melaksanakan fungsi pengawasan meliputi: 1. Dalam hal pengangkutan, pemberhentian dan penggantian pengurus dilakukan tidak sesuai dengan ketentuan Anggaran Dasar, maka atas permintaan Kejaksaan dalam hal mewakili kepentingan umum, Pengadilan dapat membatalkan pengangkatan, pemberhentian, atau penggantian tersebut (pasal 34 UndangUndang Yayasan). Demikian juga berlaku pada pengawas yang diangkat, diberhentikan atau diganti tidak sesuai dengan ketentuan anggaran dasar, maka atas permintaan Kejaksaan dalam hal mewakili kepentingan umum, Pengadilan dapat membatalkan (pasal 41 Undang-Undang Yayasan), serta berlaku terhadap pengawas (pasal 46 UndangUndang Yayasan). 2. Kejaksaan dapat mengajukan pembubaran yayasan kepada Pengadilan apabila sampai tanggal 6 Agustus 2006 yayasan yang sudah ada tidak melakukan penyesuaian anggaran dasarnya. 


\section{KEWENANGAN BERTINDAK PE- NGURUS DAN PERTANGGUNG- JAWABAN YAYASAN TERHADAP KE- 3}

Dengan diakuinya yayasan sebagai badan hukum, maka timbul masalah mengenai kewenangan bertindak pengurusnya serta pertanggungjawaban yayasan sebagai suatu "legal entity" atas tindakan-tindakan yang dilakukan pengurusnya terhadap pihak ke-3. Yayasan sebagai "legal entity" diwakili oleh pengurusnya. Menurut Setiawan, mengenai hal ini perlu dibicarakan 2 (dua) hal, yaitu "vertegen woordi'gingsmacht" ialah kekuasaan pengurus untuk mewakili guna bertindak untuk serta atas nama yayasan, dan "vertegen ... woordigingsbevoegdheid" ialah mencerminkan kewenangan mewakili atau kewenangan bertindak pengurus dengan segala persyaratan dan pembatasannya sebagaimana ditentukan dalam anggaran dasar. ${ }^{13}$

Pengelolaan kekayaan dan pelaksanaan kegiatan yayasan dilakukan sepenuhnya oleh pengurus termasuk untuk mewakili yayasan baik di dalam maupun di luar Pengadilan. Namun, dalam rangka pertanggungjawabn tugasnya, pengurus wajib membuat laporan tahunan yang disampaikan kepada pembina baik mengenai keadaan keuangan maupun perkembangan kegiatan yayasan. Maksud dan tujuan yayasan yang akan dicapai tentu tergantung dari bagaimana untuk melaksanakan kepengurusannya. $\mathrm{Hal}$ ini diatur dalam pasal 35 Undang-Undang yayasan:

Ayat (2): "Setiap Pengurus menjalankan tugas dengan itikad baik, dan penuh tanggungjawab untuk kepentingan dan tujuan yayasan".
Ayat (5): "Setiap Pengurus bertanggung- jawab penuh secara pribadi apabila yang bersangkutan dalam menjalankan tugasnya tidak sesuai dengan ketentuan anggaran dasar, yang mengakibatkan kerugian yayasan atau pihak ketiga".

Dengan demikian, pengurus menjalankan apa yang dalam kepustakaan dikenal sebagai perwakilan statuter, yaitu perwakilan berdasarkan ketentuan anggaran dasar. Masalah pokok dalam hal perwakilan statuter oleh pengurus yayasan badan hukum termasuk yayasan ialah masalah sejauh mana keterikatan yayasan sebagai suatu badan hukum terhadap tindakan pada pengurusnya, dalam hal tindakan para pengurusnya bertentangan dengan ketentuan anggaran dasar, yaitu melampaui batas kewenangan bertindaknya pengurus sebagaimana yang ditentukan anggaran dasar. ${ }^{14}$ Tugas dan kewenangan kepengurusan meliputi semua Jenis perbuatan hukum yang tercakup dalam maksud dan tujuan serta kegiatan usaha yayasan sebagaimana dimuat dalam anggaran dasarnya. Melalui pengurus selaku wakilnya, yayasan dimungkinkan mengambil bagian dalam lalu-lintas hukum sesuai dan untuk pencapaian maksud dan tujuan yayasan. Dengan demikian bahwa "maksud dan tujuan yayasan merupakan sumber kewenangan bertindak pengurus dalam mewakili yayasan di dalam maupun diluar pengadilan". ${ }^{15}$ Batas kecakapan bertindak adalah sesuai dengan maksud dan tujuan yayasan. Hal ini berarti yayasan tidak cakap melakukan perbuatan

\section{${ }^{14}$ Ibid.}

${ }^{15}$ Ratnawati W. Prasodjo, op.cit., h. 13.

${ }^{13}$ Setiawan, op. cit., h. 122. 
hukum yang tidak tercakup dalam maksud dan tujuan yayasan, yang dikenal dengan perbuatan ultra vires, pada dasarnya merupakan perbuatan batal demi hukum dan karena itu tidak mengikat yayasan. Dalam praktek tidak mudah memastikan untuk menentukan suatu perbuatan merupakan perbuatan ultra vires. Untuk itu diperlukan adanya penafsiran atas. rumusan maksud dan tujuan yayasan. $\mathrm{Di}$ samping berpedoman pada pengertian yang lazim menurut kebiasaan harus juga memperhatikan sejauh mana perbuatan itu menunjang kegiatan yayasan dalam rangka pencapaian maksud dan tujuan yayasan. Perbuatan yang dapat menunjang kegiatan usaha yayasan merupakan perbuatan yang tercakup dalam maksud dan tujuan yayasan dan karena itu merupakan perbuatan intra vires. Bagaimana tanggungjawab Pengurus berkenaan dengan perbuatan ultra vires ? Dengan memperhatikan pasal 35 ayat (5) Undang-Undang Yayasan, maka apabila yayasan mengalami kerugian yang disebabkan oleh perbuatan ultra vires, maka anggota Pengurus. yang karena kesalahannya telah menyebabkan atau ikut menyebabkan kerugian tersebut bertanggungjawab secara pribadi atas kerugian tersebut, baik terhadap yayasan maupun terhadap pihak ketiga.

Batas-batas kewenangan pengurus yayasan dalam melakukan perbuatan hukum untuk dan atas nama yayasan dapat diatur dalam anggaran dasar. Batas-batas kewenangan pengurus yayasan dengan memperhatikan ketentuan yang ada dalam Undang-Undang Yayasan, yaltu :

1. Sesuai dengan maksud dan tujuan yayasan yang bukan komersiil maka pasal 37 Undang-Undang Yayasan menegaskan bahwa pengurus tidak berwenang:
a. mengikat yayasan sebagai penjamin utang;
b. mengalihkan kekayaan yayasan kecuali dengan persetujuan pembina; dan
c. membebani kekayaan yayasan untuk kepentingan pihak lain.

2. Anggota pengurus tidak berwenang mewakili yayasan apabila :

a. terjadi perkara di depan pengadilan antara yayasan dengan anggota pengurus yang bersangkutan, dan $b$. anggota pengurus yang bersangkutan mempunyai kepentingan yang bertentangan dengan kepentingan yayasan. Di dalam Anggaran Dasar dapat ditetapkan yang berhak mewakili yayasan dalam hal keadaan tertentu (pasal 36 Undang-Undang Yayasan).

3. Guna memastikan bahwa pengurus selalu menjaga kepentingan dan mengupayakan pencapaian maksud dan tujuan yayasan, pasal 38 Undang-Undang Yayasan menentukan bahwa pengurus dilarang mengadakan perjanjian dengan organisasi yang terafiliasi dengan yayasan, pembina, pengurus, pengawas atau karyawan yayasan.

Bentuk tanggungjawab secara tanggungrenteng diterapkan dalam Undang-Undang Yayasan. Penggunaan tanggungjawab secara tanggung-renteng dilakukan apabila terjadi kepailitan. Dalam hal kepailitan karena kesalahan atau kelalaian pengurus atau pengawas dalam melakukan tugas pengawasan dan kekayaan yayasan tidak cukup untuk menutup kerugian akibat kepailitan tersebut, maka setiap anggota pengurus bertanggungjawab atas kerugian tersebut (pasal 39 dan pasal 47 Undang-Undang Yayasan). Namun, anggota pengurus atau anggota 
pengawas diberi kesempatan untuk membuktikan bahwa kepailitan tersebut bukan karena kesalahan atau kelalaiannya tidak bertanggungjawab secara tanggung-reteng atas kerugian tersebut.

$$
\text { Undang-Undang Yayasan juga }
$$

memberikan ketentuan "black list" terhadap seseorang yang tidak dapat diangkat menjadi pengurus yayasan manapun $/$ pengawas yayasan manapun apabila seseorang ini sebagai anggota pengurus / anggota pengawas yang dinyatakan bersalah dalam melakukan pengurusan yayasan / pengawasan yayasan yang menyebabkan kerugian bagi yayasan, masyarakat, atau negara berdasarkan putusan pengadilan. . Ketentuan "black list" ini berlaku selama jangka waktu 5 (lima) tahun terhitung sejak tanggal putusan tersebut memperoleh kekuatan hukum yang tetap.

Penggunaan tanggungjawab secara tanggung-renteng juga dilakukan terhadap pengurus dan pengawas apabila dokumen laporan tahunan yang, ditandatangani oleh pengurus dan pengawas ternyata tidak benar dan menyesatkan (pasal 51 Undang-Undang Yayasan). Tanggungjawab, secara tanggungrenteng ini terhadap pihak yang dirugikan, yaitu Yayasan yang bersangkutan, masyarakat, dan/atau negara.

\section{KESIMPULAN}

1. Yayasan adalah pranata hukum yang tidak berorientasi pada keuntungan melainkan melakukan kegiatan sosial, keagamaan dan kemanusiaan.

2. Dasar hukum pendirian yayasan adalah Undang-Undang Nomor 16 Tahun 2001 Tentang Yayasan, sehingga telah menimbulkan kepastian hukum dan ketertiban hukum yang dapat mengembalikan fungsi yayasan. Operasionalisasi yayasan sepenuhnya dilaksanakan berdasarkan Anggaran Dasar Yayasan yang bersangkutan. Dalam pembentukan Anggaran Dasar Yayasan tersebut harus berpedoman pada ketentuan karakteristik yayasan sebagai badan hukum sebagaimana diatur oleh Undang-Undang Yayasan.

\section{DAFTAR BACAAN}

Ali, Chidir, Badan Hukum, Alumni, Bandung. 1976.

Prasetya, Rudhi dan A. Oemar Wongsodiwiryo, Dasar-Dasar Hukum Persekutuan, tanpa penerbit, 1974.

Ratnawati W. Prasodjo, Mengembalikan Fungsi Yayasan Sebagai Pranata Hukum Dalam Rangka Mencapai Tujuan Tertentu di Bidang Sosial, Keagamaan Dan Kemanusiaan, Makalah Seminar UndangUndang Nomor 16 Tahun 2001.

Saragih, R.F., "Yayasan Dan Permasalahan Di Indonesia", Era Hukum, No.3. Th. VI Januari 2000.

Setiawan, "Tiga Aspek Hukum Yayasan", Varia Peradilan, Th. V. No.55 April 1990.

Undang-Undang Republik Indonesia Nomor 16 Tahun 2001 Tentang Yayasan (LNRI Tahun 2001 Nomor 112). 